\title{
Correction: The influence of FCGR2A and FCGR3A polymorphisms on the survival of patients with recurrent or metastatic squamous cell head and neck cancer treated with cetuximab
}

\author{
T. Magnes ${ }^{1,2,3} \cdot$ T. Melchardt ${ }^{1,2,3} \cdot$ C. Hufnagl $1^{1,2,3} \cdot$ L. Weiss $^{1,2,3} \cdot$ C. Mittermair ${ }^{1,2,3} \cdot$ D. Neureiter ${ }^{4} \cdot$ E. Klieser ${ }^{4}$. \\ G. Rinnerthaler ${ }^{1,2,3} \cdot$ S. Roesch ${ }^{5} \cdot$ A. Gaggl $\left.\right|^{6} \cdot$ R. Greil $^{1,2,3} \cdot$ A. Egle ${ }^{1,2,3}$
}

Published online: 18 January 2019

(c) The Author(s) 2019. This article is published with open access

\section{Correction to: The Pharmacogenomics Journal; https://doi.org/10.1038/tpj.2017.37; published online 18 July 2017}

In the abstract and in other parts of the manuscript the authors wrote that the mutation rs396991 causes a valine (V) to phenylalanine (F) substitution at position 157. However, the correct codon number is 158 . These errors have not been fixed in the original article.
These authors contributed equally: T. Magnes, T. Melchardt

The original article can be found online at https://doi.org/10.1038/tpj. 2017.37.

A. Egle

a.egle@salk.at

1 Department of Internal Medicine III with Hematology, Medical Oncology, Hemostaseology, Infectious Disease, Rheumatology, Oncologic Center, Laboratory for Immunological and Molecular Cancer Research, Paracelsus Medical University, Salzburg, Austria

2 Salzburg Cancer Research Institute (SCRI), Salzburg, Austria

3 Cancer Cluster Salzburg (CCS), Salzburg, Austria

4 Institute of Pathology, Paracelsus Medical University, Salzburg, Austria

5 Department of Otorhinolaryngology, Head and Neck Surgery, Paracelsus Medical University Salzburg, Salzburg, Austria

6 Department of Oral and Maxillofacial Surgery, Paracelsus Medical University Salzburg, Salzburg, Austria
Open Access This article is licensed under a Creative Commons Attribution 4.0 International License, which permits use, sharing, adaptation, distribution and reproduction in any medium or format, as long as you give appropriate credit to the original author(s) and the source, provide a link to the Creative Commons license, and indicate if changes were made. The images or other third party material in this article are included in the article's Creative Commons license, unless indicated otherwise in a credit line to the material. If material is not included in the article's Creative Commons license and your intended use is not permitted by statutory regulation or exceeds the permitted use, you will need to obtain permission directly from the copyright holder. To view a copy of this license, visit http://creativecommons. org/licenses/by/4.0/. 